\title{
NAF1 wt Allele
}

National Cancer Institute

\section{Source}

National Cancer Institute. NAF1 wt Allele. NCI Thesaurus. Code C113131.

Human NAF1 wild-type allele is located in the vicinity of $4 q 32.2$ and is approximately 57

$\mathrm{kb}$ in length. This allele, which encodes H/ACA ribonucleoprotein complex non-core subunit NAF1 protein, is involved in riboprotein assembly. 